\title{
Scientific Basis of Agroforestry Homegardens in Matara District, Sri Lanka: Present Status and Improvement Needs
}

\author{
Mangala De Zoysa \\ Department of Agricultural Economics, University of Ruhuna, Mapalana, Kamburupitiya, Sri Lanka \\ Email: mangalaxyz@yahoo.com
}

How to cite this paper: De Zoysa, M. (2022). Scientific Basis of Agroforestry Homegardens in Matara District, Sri Lanka: Present Status and Improvement Needs. Open Journal of Forestry, 12, 60-87.

https://doi.org/10.4236/ojf.2022.121004

Received: October 3, 2021

Accepted: January 4, 2022

Published: January 7, 2022

\section{Copyright () 2022 by author(s) and} Scientific Research Publishing Inc. This work is licensed under the Creative Commons Attribution International License (CC BY 4.0).

http://creativecommons.org/licenses/by/4.0/

\begin{abstract}
High diversity of species in agroforestry homegardens play main agro-ecological roles in complex and sustainable land use systems. Efforts are being made in valuing and protecting the age-old practices of agroforestry on scientific basis in homegardens. This study attempted to analyse the scientific basis of households' practices and to develop strategies for the promotion of sustainable agroforestry homegardens in Matara district of Sri Lanka. Selected households were interviewed measuring their concern using 5-point Likert scale, and analysed the qualitative data using non-parametric statistics. The study revealed that scientific basis of household practices in agroforestry homegardens are moderate in selection of appropriate trees and plants, and management of trees and plant health care. Households pay little concern on scientific basis in planning and site placement, land preparation and establishment of trees/crops, and implementing proper cultural practices. There is no significant correlation between scientific basis of practices in agroforestry in relation with size of homegardens, educational level of households, and across the category of their occupations. Resources to use scientific knowledge in practice, and opportunity to improve scientific skills have moderate correlation significantly while availability of scientific information and access to scientific knowledge have significant but low correlation as applying knowledge on scientific basis. The interest to acquire scientific knowledge, and sufficient time to improve scientific knowledge, and other reasons have no significant correlation with scientific basis of household practices. Carefully planned interventions including policy adjustments and effective extension programs for learning and experimenting together with supportive programs would enhance scientific basis of household practices for agroforestry in homegardens.
\end{abstract}

\section{Keywords}

Homegarden Composition, Plants Selection, Health-Care Management, 
Resources Use, Agroforestry Policy

\section{Introduction}

\subsection{Agroforestry Homegardens}

Agroforestry homegardens are unique land-use systems involving the deliberate management of multipurpose trees and shrubs in intimate association with annual, perennial, and seasonal agricultural crops, and perhaps livestock within the compounds of individual homes. Agroforestry homegardens are emphasized as in-situ germplasm conservation of native plant species which are deliberately preserved (Baig et al., 2008). Agroforestry homegardens is a complex sustainable land use system which provides environmental services, domestic needs, and income generation opportunities to the household. The high diversity of species produce food and a wide range of other products such as firewood, fodders, spices, medicinal plants and ornamentals and play main agro-ecological roles of the homegardens. Agroforestry homegardens provide income and livelihood opportunities for resource-poor households while delivering number of ecosystem services. Multi-strata agroforestry homegardens are sustainable and profitable particularly in the tropical developing countries. Homegardens are an integral part of local food systems in developing countries and enhance household food security and nutrition (Galhena et al., 2013). As woody perennial-based mixed species production systems, agroforestry homegardens ensure food diversity and contribute to food security during the lean seasons (Kumar \& Nair, 2004). Agroforestry practices in homegardens are very depending upon site-specific factors based on the nature of components. The households often establish agroforestry in homegardens basically using indigenous knowledge and traditional practices reflecting long-term economic interferences, social interactions, cultural norms and values, environmental experiences and ecological associations. They often use indigenous knowledge and traditional practices in agroforestry homegardens to obtain some benefits from complimentary uses of annuals and woody perennials.

\subsection{Scientific Basis}

The scientific basis of the design for landscape sustainability with broad range local species is a complex phrase. The location-specific information on agroforestry homegardens which are long time practices, have been little studied (Nair, 2001). The scientific basis of knowledge is held tentatively in public which is subjected to change based on contrary evidence. A belief can be justified by scientific evidence as a factual claim as the evidence is empirical, replicable, verifiable and public (Boshoff, 2014). Scientific basis of practices of households would have further enriched the agroforestry in traditional homegarden system. Due to the inherent diverse strands of knowledge and practice, agroforestry is 
associated with complexity in development of scientific basis (Mbow et al., 2014). Agroforestry homegardens were therefore continued without enough incursion of science from the pre-scientific agricultural days (Nair, 2001). Scientists did not realize the importance and potential contribution, and improving traditional systems to the framework of the development of agroforestry homegardens. Underlying scientific foundations of homegardens had not been fully explored and not even considered as a part of development agendas (Nair, 1993). The promotion of strategies to improve the scientific basis of practices of households in agroforestry homegardens has become an emerging trend. Agroforestry has become a hotspot in scientific research because only few studies have attempted to review agroforestry for scientific development over time and by regions (Liu et al., 2019). The scientific basis for the rational use of plant resources and other technical protection measures of agroforestry homegardens have become a new field in the research area. The multicomponent, multiproduct nature of agroforestry homegardens requires the scientific basis for the complex management and cropping technologies. Research attention should be focused on understanding of agroforestry the multi-strata systems, and sharing of growth resources by agroforestry particularly the diversity, complexity, and value of homegardens, functionally and scientifically (Nair, 2001).

\subsection{Agroforestry Transformation}

A considerable progress in transferring the age-old agroforestry practices into a scientific basis has been achieved during the recent decades. Scientific basis of the body of knowledge and set of practices in agroforestry explore and guide mixed agricultural systems at nested scales. The World Agroforestry Centre has made significant efforts in developing scientific basis of agroforestry systems during the past three decades (Rao et al., 2007). Agroforestry are being transformed from a practice in search of science into a science-based practice as an integrated applied science addressing some of the land-management and environmental problems (Nair, 2007). Scientists, especially ethno-botanists are paying increasing attention for traditional agro-ecosystem in homegardens as germplasm banks for many crops and other economic plants (Huai \& Hamilton, 2009). The attributes of practices and other situational factors which facilitate and impede the use of scientific basis in practices are less known. Existing usage and consumption behaviours; perceived value; functional, physical, social, financial and time risks; and psychological factors in background, attitude, belief, lifestyles, and culture are considered as the basic barriers to the adoption of scientific knowledge or practices. Long standing homegardens today are testing grounds of many continuous generation, dissemination and adoption of innovations and improvement of effective strategies.

Translation of practice for scientific basis could influence the adoption and dissemination of innovations (Scott et al., 2008). Unless the households improve the scientific basis of their practices, the potential benefits of agroforestry in 
homegardens may not be realized. Households are the initiators of transformative change of land use management practices integrated with agroforestry within rural livelihood systems considering favourable biophysical conditions, appropriate tree and crop germplasm (Mbow et al., 2014). The scientific basis of agroforestry practices in homegardens has to be studied empirically in close interactions with households. The traditional agroforestry practices of local households form the basis for conducting rigorous research to address many environmental and social concerns (Brown et al., 2018). Even with an explosion of research on the adoption of agroforestry innovations, agroforestry homegardens requires an understanding of a perceived knowledge and practices of households on advances in agroforestry science and their success of agroforestry in homegardens. Scientific basis of practices in terms of individual needs and individual perceptions used to achieve those needs determine the adoption of new practices (Thangata \& Alavalapati, 2003).

\subsection{Agroforestry Homegarden Promotions in Sri Lanka}

The area of homegardens in Sri Lanka was estimated at 977,700 ha in 2005 almost $17 \%$ of total lands with the increasing in extent of $1 \%$ per year until 2020 (FAO, 2009). Establishment and expansion of homegardens has become a recent governmental policy in Sri Lanka with the view of reducing living costs and imports of food products, enhanced food security, maintenance of environmentally friendly agroforestry through extension support, identification and creation of market conditions (Chokkalingam \& Vanniarachchy, 2011). The national development policy framework of Sri Lanka has emphasized to expand and improve food and timber productions promoting traditionally developed homegarden agroforestry systems innovation and practicing in the village level. Many national development programs mainly "Haritha (Green) Lanka"; "Api Wawamu Rata Nagamu" (Let us grow, and uplift the nation); "Deyata Sevana" (the national tree planting programme); "Divi Neguma" (Livelihood Development) are developing strategies for the promotion homegardens through scientific basis of agroforestry. The "Hritha (Green) Lanka" program of 2009 has highlighted the importance of promoting the homegardens through application of scientific basis of agroforestry practices (NCSD, 2009).

Although the modern scientific basis is relatively new, agroforestry in homegardens is an ancient practice with traditional knowledge in Sri Lanka for centuries. Understanding the knowledge of local households on human-ecological relationship in homegardens is necessary for the change in homegardens sustainable development (DeHaan et al., 2020). Scientific advancement in promotion of practices is required for cognitive development of households for sustainable development of agroforestry in homegardens (Jeyavanan et al., 2017). It is time to begin to collect cross-sectional data on scientific basis agroforestry practices in homegardens in Sri Lanka with the view of promotion of agroforestry homegardens through adoption of innovations. Hence the objectives of the study are: 
to examine households and agroforestry in homegardens; to ascertain the scientific basis of the practices of households for agroforestry homegardens; to analyses the characteristics of households and homegardens affecting scientific basis of households practices for agroforestry homegardens; and to develop strategies for the improvement of scientific basis of household practices for agroforestry homegardens.

\section{Methodology}

The case study was conducted interviewing 68 householders possessing homegardens selected from $3 \mathrm{GN}$ (Grama Niladari) divisions in Matara district. Multi-species, multi-storied and multi-purpose vegetation situated close to the homestead were considered as agroforestry in homegardens in the study area. The 3 villages: Uninduwela in Malimboda, Panatiyana East in Welipitiya and Hikkoda in Akuressa Divisional Secretariat divisions were selected for the study through reconnaissance survey conducted with district and agricultural office experts. The random selection of the households from each village was done based on a list held by the agricultural extension officer. The primary data were collected from selected 68 households by personal interviews conducted by the researcher through the use of a structured questionnaire which was pre-tested to check for clarity and improve reliability. The questionnaire contained both open and closed form of questions. With the help of households, species composition of homegarden were recorded. The scientific basis of household practices in agroforestry homegardens and strategies for the promotion of scientific basis of household practices for agroforestry homegardens were measured using the " 1 5" "5-Point Likert Scale". Observations were made on the households and their homegardens concerning the general condition of their agroforestry practices. Data collected from the interviews were coded, analysed, interpreted and synthesized. Statistical Package for the Social Sciences was used for the analyses of data descriptively as well as statistically using non-parametric tests.

\section{Size of Homegardens, Education and Occupations of Households, and Agroforestry Composition}

\subsection{Size of Homegardens and Education of Households}

Households practice agroforestry in homegardens as common and popular sustainable land use systems in Sri Lanka in terms of economic, social, cultural and environmental perspectives. Traditional agroforestry homegardens have complicated structures, diverse floristic compositions, multiple functions, low input including labour and money, and ecological and socioeconomic sustainability (Huai \& Hamilton, 2009). The scientific basis of practices of the agroforestry homegardens is a function of the specific characteristics of the individual households. The size of homegardens in the study area is estimated as average 0.37 ha (mean) and size of majority households 0.40 ha (median) (Table 1). The study area belongs to the category of peri-urban area according to the administrative 
Table 1. Size of homegarden and education of households.

\begin{tabular}{ccccc}
\hline & Mean & Median & Minima & Maxima \\
\hline \multirow{2}{*}{ Size of Homegarden } & $0.92 \mathrm{Ac}$ & $1.00 \mathrm{Ac}$ & $0.25 \mathrm{Ac}$ & $3 \mathrm{Ac}$ \\
& $(0.37 \mathrm{Ha})$ & $(0.40 \mathrm{Ha})$ & $(0.10 \mathrm{Ha})$ & $(1.21 \mathrm{Ha})$ \\
Education of Households & Grade 9 & Grade 9 & Grade 6 & Grade 12 \\
\hline
\end{tabular}

divisions in Sri Lanka. Hence the average size of homegardens in the study area is high compared to urban areas but low compared to the rural areas. Homegardens in Sri Lanka is categorized as a piece of land area between 0.05 and 2.5 ha (mean $0.4 \mathrm{ha}$ ) no larger than 1 ha typically with some form of cultivation, which has a dwelling house (Pushpakumara et al., 2012; DeHaan et al., 2020). Agroforestry homegardens in tropical and subtropical regions are very often small sized much less than one hectare land use systems particularly in the rural ecosystems (Kumar \& Tiwari, 2017). Average as well as the majority of the head of households have educational level of Grade 9 (Secondary Schools) with minimum Grade 6 and maximum Grade 12 (Secondary Upper School). All the households express their interest and have sufficient education to manage agroforestry in their homegardens. The impressive Human Development Indicators of Sri Lan$\mathrm{ka}$ as a lower-middle-income country show that about $96 \%$ of its citizens have completed primary school, while $87 \%$ have finished secondary school (Dundar et al., 2017). Further, agriculture and agroforestry in school gardens and homegardens are common subject matters in the classroom teaching as well as in practical classes. FAO together with the Ministry of Education in Sri Lanka have conducted training workshops in 6000 schools in order to popularize school gardens for child nutrition and life skills (FAO, 2017).

\subsection{Households' Occupations}

The main occupations of the households are: $27 \%$ farmers; $20 \%$ family business, $17 \%$ private sector jobs and $17 \%$ government sector jobs while $20 \%$ households have no proper occupation (Table 2). The households in the study area are involving in non-farm occupations (73\%) and possess home gardening on part-time basis based on the availability of their leisure time. The head of the households and the housewives are usually involving in home gardening. In general, agroforestry in homegardens improve nutritional status and provide additional income for the households occupied in low-paid employment (Amenu, 2017). Even the households under the category of farming and no proper occupation in the study do not have regular schedule for working in their homegardens. Agroforestry homegardens involve no cost of labour as all the activities are operated by the family labour in the study area. Many studies have estimated that agroforestry with different combination of crops and trees in homegardens in Sri Lanka requires only low costs for inputs also on a daily basis (Mattsson et al., 2017). 
Table 2. Occupations of households.

\begin{tabular}{ccc}
\hline Occupations & Number & Percentage \\
\hline Farmers & 18 & 27 \\
Government Jobs & 11 & 16 \\
Private sector Jobs & 11 & 17 \\
Family business & 14 & 20 \\
No proper occupation & 14 & 20 \\
Total & 68 & 100 \\
\hline
\end{tabular}

\subsection{Agroforestry Composition}

Agroforestry homegardens in Sri Lanka are typically multi-strata systems and characterized by a high density of multiple species that exhibit complex structure, both attributes and ecological services. Each household design and manage homegardens that varies in size, creating diversity based on spatial configuration and other factors including selection of species (DeHaan et al., 2020). The environmental and socioeconomic factors determine the choice of species, species composition among different homegardens (Nair, 1993). Uses of their practices in homegardens have similar prospects for the management of agroforestry. An interdisciplinary approach to land use from a set of integrated land use practices propose the definition of agroforestry (Sinclair, 1999). However, only few studies have been conducted on historical changes of species composition and dynamism of homegardens in Sri Lanka (Pushpakumara et al., 2012). According to the study, Ornamental plants (23.5\%), fruit trees (20.7\%) and vegetables (18.7\%) dominate the agroforestry composition of homegardens according the occupying land extents by each in the study area (Table 3). The primary emphasis of homegardens as an integral part of local food systems in the study area, is the cultivation of trees/crops. They give priority for growing food crops including vegetable, leafy vegetables, root crops fruits and spices covering all together $55.8 \%$ of the land extent, mainly for household consumption and use. Among the food crops, fruit crops occupy the substantial (20.7\%) extent of land producing a main ingredient adding to the daily nutrient supplements of the household. Homegardens in Sri Lanka with crop biodiversity and organized agroforestry practices contributed significantly to micronutrient intake and dietary diversity of the households (Thamilini et al., 2019). Some excess homegarden products mainly fruits and vegetables in the study area are shared with other households, their neighbours and relatives. Households give homegarden products to strengthen neighbour and family relationship called social capital (Linger, 2014). Although the agroforestry products produced in homegardens in the study area do not presently improve the income generation or financial status of households, there is a greater potential for contribution to income generation in addition to the household food security. Homegardens dominated by fruit tree species provide significant higher financial status for the households (Park et al., 2019). 
Table 3. Agroforestry composition in homegardens.

\begin{tabular}{ccc}
\hline Type of Crops/Trees Species & $\begin{array}{c}\text { Average Number of Crops/ } \\
\text { Trees per Homegarden }\end{array}$ & \% of Average Land Extent \\
\hline Ornamentals & $12(18)$ & 23.5 \\
Vegetables & $8(12)$ & 10.3 \\
Leafy Vegetables & $4(6)$ & 8.4 \\
Root Crops & $4(6)$ & 6.3 \\
Fruits & $10(15)$ & 20.7 \\
Spices & $6(9)$ & 10.1 \\
Timber Species & $6(9)$ & 11.6 \\
Others & $16(24)$ & 9.1 \\
Total & $66(100)$ & 100 \\
\hline
\end{tabular}

${ }^{\star}$ Percentages are in parentheses.

Orchard intercropping shade loving crop with early stage of fruit trees in agroforestry system is a viable option for successful crop diversification and increasing the income (Ali et al., 2018).

The households give the priority for growing ornamental plants in order to create beauty in their homegardens is a traditional and cultural practice. They often relax under the shade in homegardens during the day times and also during the leisure time with their family members. They grow some flowering trees purposely because worship of Lord Buddha offering flowers is a common practice of the households. Households prefer ornamental plant displaying the beauty of their homegardens, and provides attractive and aesthetic value indicating their prestige (Ortíz-Sánchez et al., 2015). The households rate significantly high and very important relations growing trees in homegardens for ornamental and aesthetic purposes creating relaxing and fresh environment (Jeyavanan et al., 2017). Timber tree species (11.6\%) have been mainly grown in the fences surrounding homegardens for the purposes of demarcation and protection of the land, adaptation to the impacts of blowing winds as well as to produce timber for domestic use. The high species density homegardens in Sri Lanka consists of high accounted mean volume of producible trees $\left(36.68 \mathrm{~m}^{3}\right.$ per ha) and poles (2.12 $\mathrm{m}^{3}$ per ha) (Jeyavanan et al., 2017).

\section{Scientific Basis of Households, Practices}

Agroforestry practices in homegardens are directly connected to multipurpose uses and to satisfy household requirements. Agroforestry homegardens as a viable land-use option in a multifunctional landscape offers a number of ecosystem services and environmental benefits (Jose, 2009). Agroforestry practices are common where trees are used in various productive niches within the homegardens. To group the agroforestry that are similar, uses the practice rather than the system as the unit of classification (Sinclair, 1999). Agroforestry homegardens 
involving practices with concern of a set of techniques developed by households over the decades, based on their observations and experimentations. The practice of agro forestry in homegardens are age-old sustainable systems which has been developed and nurtured by households through generations of innovations and experiments (Amenu, 2017). The scientific basis of practices by households for agroforestry in homegardens in the study area was examined in terms of: planning and site placement; land preparation and establishment of crops/trees; selection of appropriate trees and plants; implementing proper cultural practices; and management of tree and plant health care (Table 4).

Table 4. Scientific basis of households' concern on agroforestry management practices.

\begin{tabular}{|c|c|c|c|}
\hline Household Practices & Mean & Median & St. Deviation \\
\hline Planning and site placement & $(2.3)$ & $(3.0)$ & $(0.97)$ \\
\hline a. Access to the sun light & 2.3 & 2.0 & 1.06 \\
\hline b. Direction of wind & 2.5 & 2.0 & 0.78 \\
\hline c. Management of soil fertility and conservation & 2.6 & 3.0 & 0.93 \\
\hline d. Supply of water & 1.8 & 2.0 & 0.83 \\
\hline e. Convenience for management practices & 2.2 & 2.0 & 0.97 \\
\hline Land preparation and establishment of crops/trees & $(2.4)$ & $(2.3)$ & $(0.56)$ \\
\hline a. Arrange water drainage system & 2.5 & 2.0 & 1.17 \\
\hline b. Amend soil acidity & 2.0 & 2.0 & 0.74 \\
\hline c. Prepare soil conservation structures & 2.5 & 3.0 & 0.73 \\
\hline d. Alter light conditions & 2.4 & 2.0 & 0.89 \\
\hline Selection of appropriate tree/plants & $(2.7)$ & $(3.0)$ & $(0.59)$ \\
\hline a. Know the requirements of a plant before selection & 3.2 & 4.0 & 0.76 \\
\hline b. Growing right plant in right place & 2.0 & 2.0 & 0.89 \\
\hline $\begin{array}{l}\text { c. Selecting drought and disease resistant varieties/ } \\
\text { cultivars }\end{array}$ & 2.7 & 2.0 & 1.21 \\
\hline d. Selecting high quality planting materials & 3.5 & 4.0 & 0.68 \\
\hline Implementing proper cultural practices & $(2.2)$ & $(2.0)$ & $(0.66)$ \\
\hline a. Moisture management & 2.1 & 2.0 & 0.74 \\
\hline b. Planting techniques and maintenance & 2.1 & 2.0 & 0.76 \\
\hline c. Frequency and timing of soil fertility management & 2.6 & 3.0 & 0.82 \\
\hline Management of tree and plant health care & $(2.8)$ & $(3.0)$ & $(0.94)$ \\
\hline a. Management of pests & 2.8 & 3.0 & 0.97 \\
\hline b. Protection of other beneficial organisms & 1.2 & 1.0 & 0.41 \\
\hline c. Control of weeds & 2.6 & 2.0 & 1.38 \\
\hline d. Prevention of diseases & 2.9 & 3.0 & 0.96 \\
\hline
\end{tabular}

Likert Scale: Not concern-1; little concern-2; Moderate concern-3; highly concern-4; and fully concern-5. 


\subsection{Planning and Site Placement}

The mean value (2.3) implies that the households pay overall little concern on scientific basis in planning and site placement of agroforestry in homegardens (Figure 1). The households usually pay general concern about biodiversity conservation through planting crops and trees time to time which is one of the important strategy for ensuring diverse productions and ecosystem services in homegardens. Agroforestry homegardens represent large fraction of the total land area in human dominated landscapes have been proven to be an intermediary for biodiversity conservation (Bardhan et al., 2012). The agroforestry practices in time and space deal with distinct successional phases in long rotations in homegardens (Sinclair, 1999).

The mean values indicate that the households moderately concern scientific basis on the direction of wind (2.5), and the level of soil fertility (2.6). They consider the direction of blowing wind particularly in planting different type of perennial crop and timber trees in order to minimize wind damages to crops, buildings and other properties in their homegardens. Sri Lanka Comprehensive Disaster Management Program 2014-2018 (SLCDMP) has identified high winds/cyclones as one of the major types of disasters closely associated with extreme weather events in Sri Lanka (Climate Change Secretariat, Ministry of Mahaweli Development and Environment, 2016). The households have experience about improvement of soil chemical and physical properties by multi-cropping systems particularly with legumes of agroforestry in homegardens. A study shows, the indigenous homegarden agroforestry systems use diverse tree species involving intercropping and set of traditional techniques developed based on observation and experimentation for centuries in order to promote soil properties (Pinho et al., 2012). They little concern about the scientific basis on access to

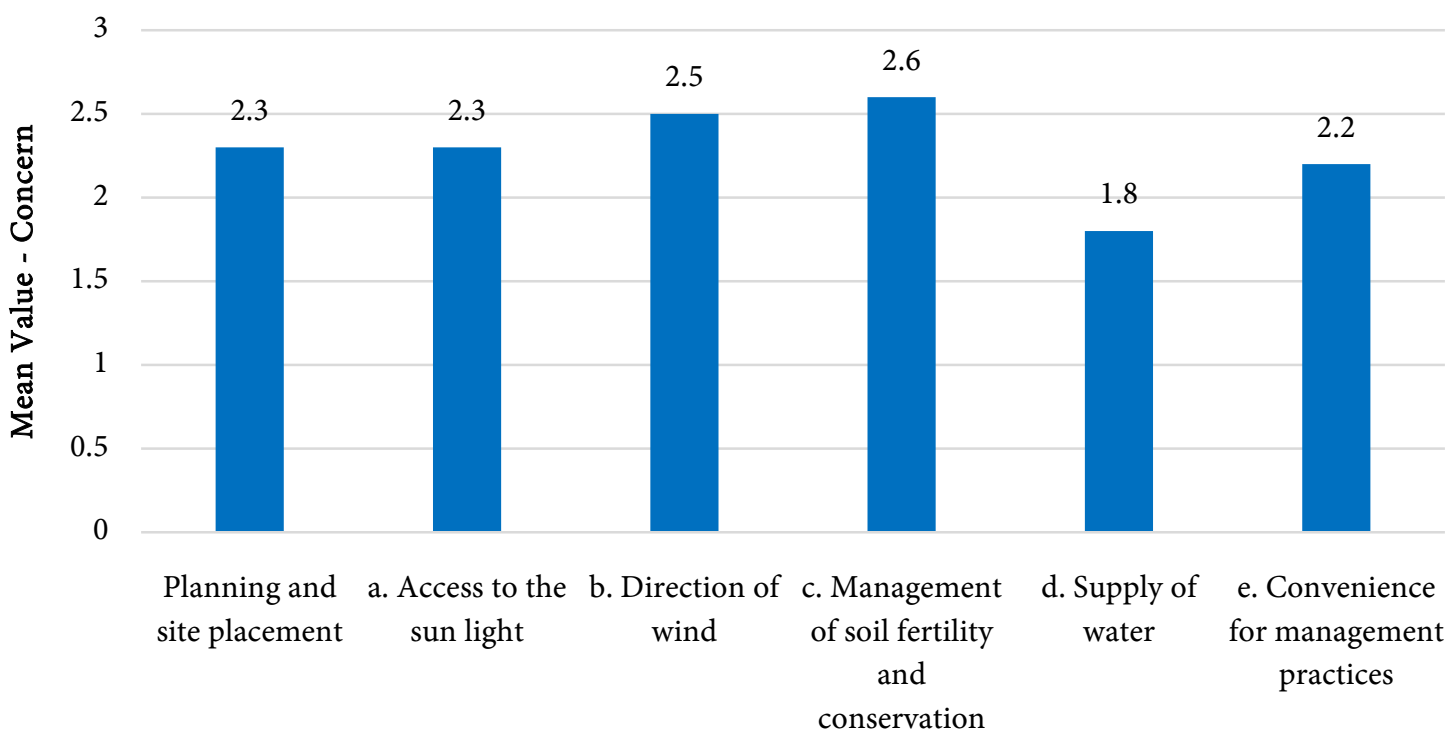

Practices

Figure 1. Planning and site placement. 
the sun light (2.3); convenience for management practices (2.2); and the supply of water (1.8). Higher level of shade inside the homegardens are common with richness of ornamental tree species in agroforestry systems in the study area belong to the wet zone in Sri Lanka. However, the households grow tress in homegardens with the intension of maintaining lower temperature compared to outside of the homegardens by increasing shade level, with their long term experiences (Jeyavanan et al., 2017). Although the scientific basis is little concerned by the households in convenience for management practices, and water management practices in agroforestry homegardens, the ornamental, and fruit plants are located close to the homestead to make the homegardens more attractive and facilitate their easy care. Family labour requirement for work in homegardens are weeding, and carrying water from the wells and frequent watering mainly the ornament plants, vegetable and other agricultural crops. About how beneficial different plants and how much water they consume is a gap of scientific basis in area of water management practices in homegardens (Mattsson et al., 2017).

\subsection{Land Preparation and Establishment of Crops/Trees}

The households have overall little concern (2.4) on scientific basis in land preparation and establishment of crops/trees in homegardens (Figure 2). The households prepare lands as a usual practice and establish crops and trees based on the availability of preferred and reliable planting materials from the government programs and their neighbours. Trees and associated crops may outcompete for nutrients, growing space, and light and soil moisture and may reduce

3

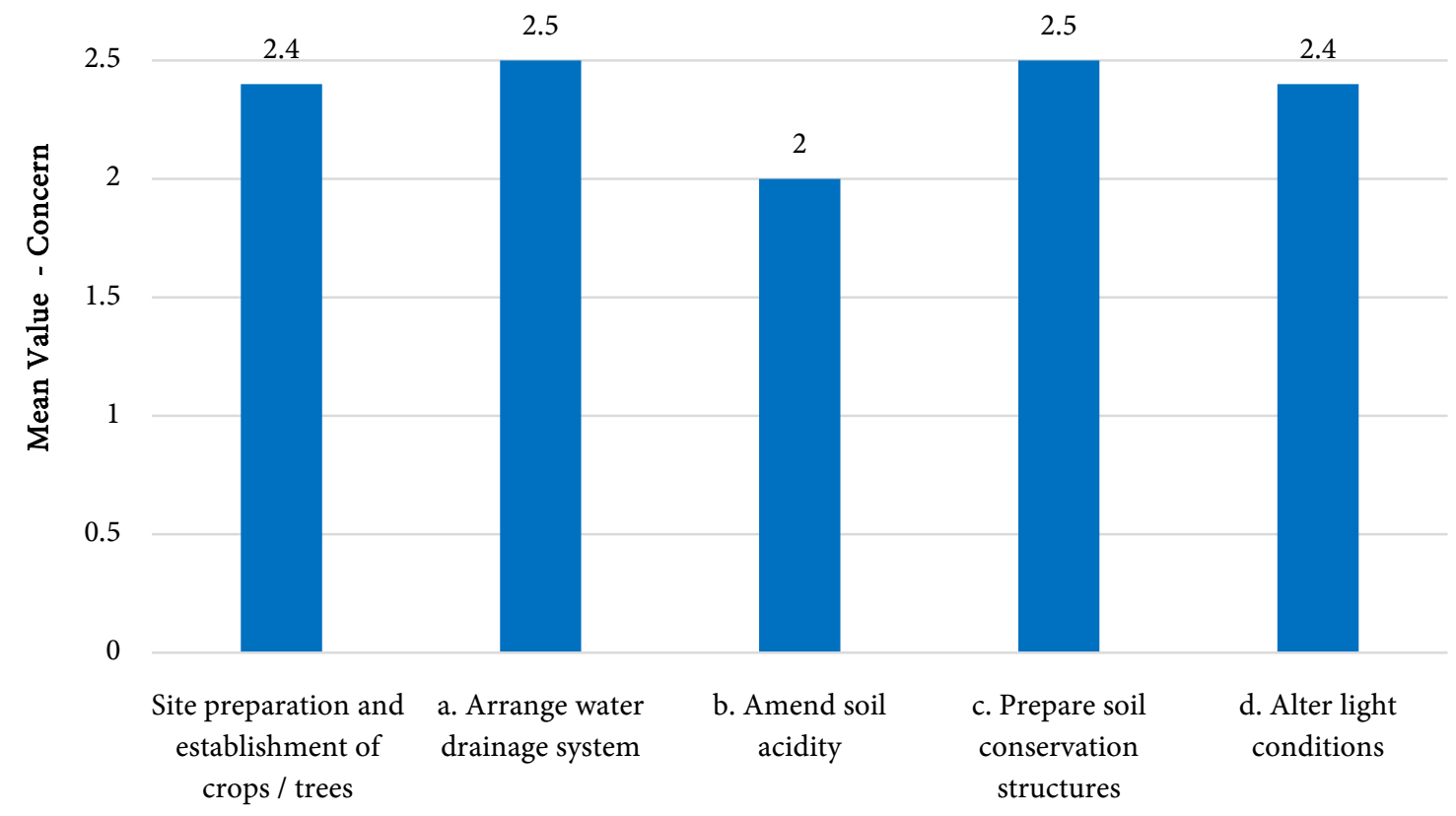

Practices

Figure 2. Land preparation and establishment of crops/trees. 
the yields without much notice for the households. Agroforestry has less scope for vertical root complementarity but mixed and superficial tree root architectures are common to recharge water and absorb available nutrients (Ong \& Swallow, 2004).

They moderately concern the scientific basis on arrangement of water drainage system (2.5) and prepare soil conservation structures (2.5). The households who have recognized soil erosion problems in their homegardens are less likely to understand the scientific knowledge of soil conservation technologies in agroforestry. They have experiences that agroforestry homegardens play an important role in the conservation of biodiversity. Agroforestry practices with multipurpose trees and multilayer trees are the major specific approaches for soil conservation hedges in homegardens, which are common in Sri Lanka. These practices are based on the long term experiences of the households. Households may in some occasions destruct plant diversity in homegardens due to lack of scientific knowledge resulting soil erosion during high rainfall, and food insecurity during drought period (Linger, 2014). However, a study in Sri Lanka has revealed that the households perform conservation practices significantly regulating and enhancing soil, nutrient, water and biodiversity in homegardens (Jeyavanan et al., 2017). The households pay little concern the scientific basis about amending soil acidity (2.0) and altering light conditions (2.4) in homegardens. The households are aware of soil acidity but not experiencing any impact on the vegetation in homegardens. Homegardens preserve some chemical properties of soil similar to the secondary forest in nutrient cycling and soil fertility which is also explained by soil acidity (Thiago et al., 2016). They are knowledgeable but pay only little concern about intensity of sunlight and shadiest spots in their homegarden before establishment of crops and trees. They have limited possibility to change the shade and light conditions due to less organized agroforestry systems in homegardens. The impact of solar radiation on growth of plants not only depend on the competition and complementarity between trees and understory agricultural crops but also the species, space, and soil factors (Rao et al., 2007).

\subsection{Selection of Appropriate Trees and Plants}

Scientific basis of the selection of appropriate trees and plants in overall are moderately concern (2.7) by the households in agroforestry homegardens (Figure 3).

Majority of the households have the concern of scientific basis on the right tree species that can be used to integrate properly in their homegardens. Households deliberately manage multipurpose trees and shrubs in intimate association with herbaceous species in their homegardens as a successful traditional land use practice (Kumar \& Tiwari, 2017). Ecologically adapted and complementary species are generally featured in homegardens with low capital inputs and simple agroforestry technology. Variety of components and species of the agroforestry 


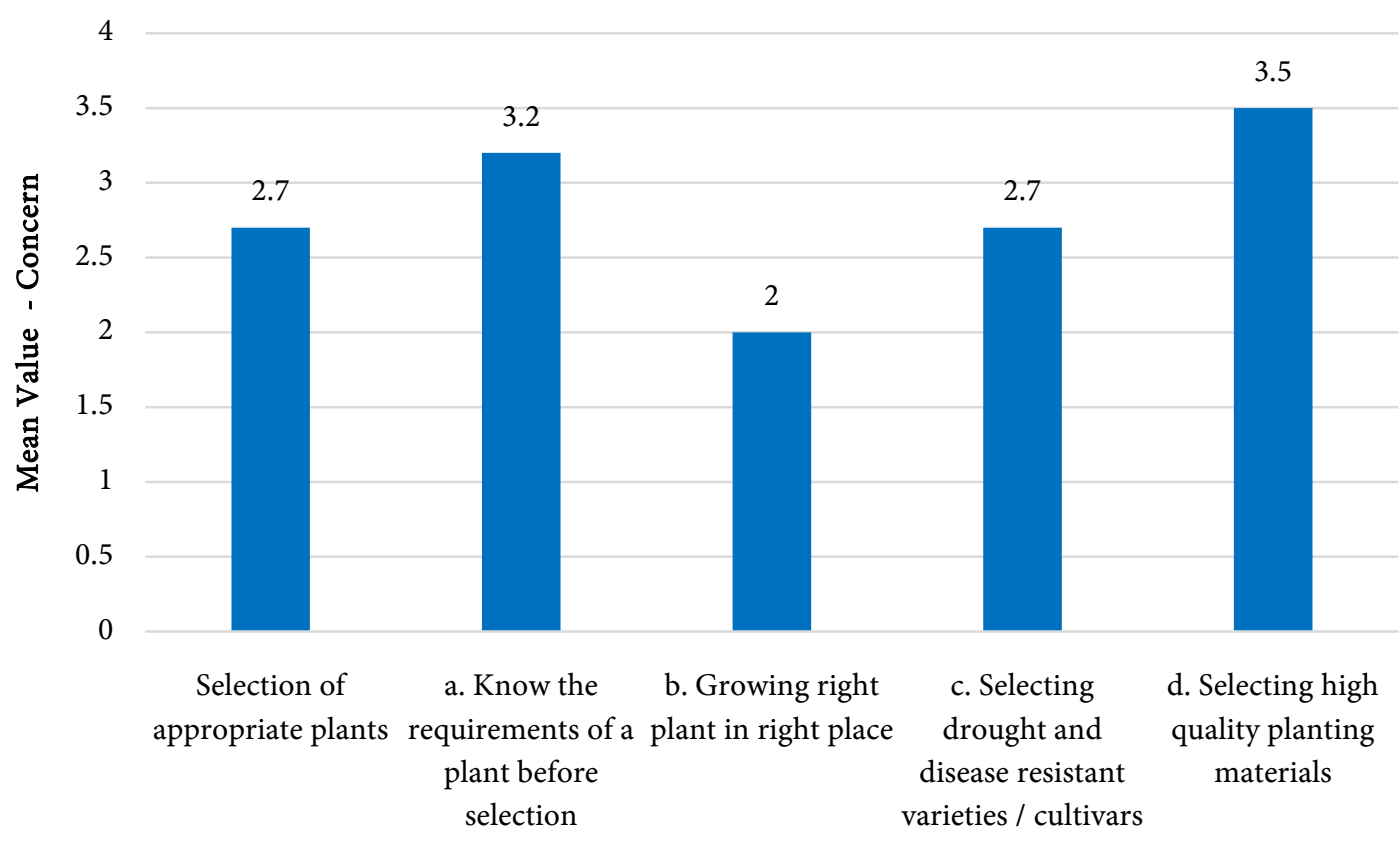

Practices

Figure 3. Selection of appropriate trees/plants.

systems represent social and traditional aspects (Galhena et al., 2013). The households are highly concern about the scientific basis in selecting quality of planting materials (3.5). They are knowledgeable and have experienced on the methods of successful propagation, selection appropriate planting material and utilization of healthy planting materials of most of the plants they usually grow in homegardens. As a new trend, they purchase few ready to plant potted quality planting materials for fruits and ornamental plants from the nearby commercial nurseries. The households are moderately concern scientific basis about requirements of a plant before selection (3.2) and selecting drought and disease resistant varieties or cultivars (2.7). Usually, agroforestry in homegardens in Sri Lanka have infinite number of arrangements and species combinations that depend on objectives of households and the environmental characteristics and ecological distribution. The households select species for homegardens targeting their nutrient supplement and harvest various food products daily depending on seasonal variations (Yapa, 2018). Presence of multi-layered agroforestry homegardens in the study area facilitates efficient use of resource and ecological functions, provides habitat to soil micro-organisms and promote a favourable microclimate for the households. Households deliberately plant mixture of vegetation in homegardens with a complex structure and design to produce products for the domestic purpose or market requirement (Kabir \& Webb, 2009). The households are often experiencing prolong droughts and rainy periods from recent past as a result of the climate change impacts. They pay especial concern on selecting drought and disease resistant plants in order to minimize the difficulties associate with watering and management of healthy vegetation in homegar- 
dens. The households increase resilience of both agroforestry systems in homegardens and their management capacity as adaptation strategy for climate change impacts (Gifawesen et al., 2020). The households pay little concern scientific basis in growing right plant in right place (2.0). Almost all the homegardens in the area are not properly organized agroforestry systems. They often change plant composition of the agroforestry systems through gap-filling strategy using available planting materials or finding space for a favourite species selected on personal interest. Many national programs promoting homegarden development have mixed outcomes due to insufficient involvement of households because the species provided have not always matched with their needs and knowledge capacities (Mattsson et al., 2017).

\subsection{Implementing Proper Cultural Practices}

The households are little concern about the scientific basis of the overall implementation of proper cultural practices (2.2) due to complex combination of crop biodiversity (Figure 4). The agroforestry systems in homegardens are not properly organized and their cultural practices are often conducted on ad hoc basis. The scientific basis of households' practices on agroforestry competition for resources remains imperfect due to the complex nature of the interactions and difficulties associated with quantification (Rao et al., 2007). They moderately concern scientific basis about the frequency and timing of soil fertility management (2.6). Although the agroforestry is an attractive and sustainable pathway to improve soil fertility, without adequately fertilizing or fallowing the land while nutrient mining from continuous harvesting in agroforestry homegardens is the

3

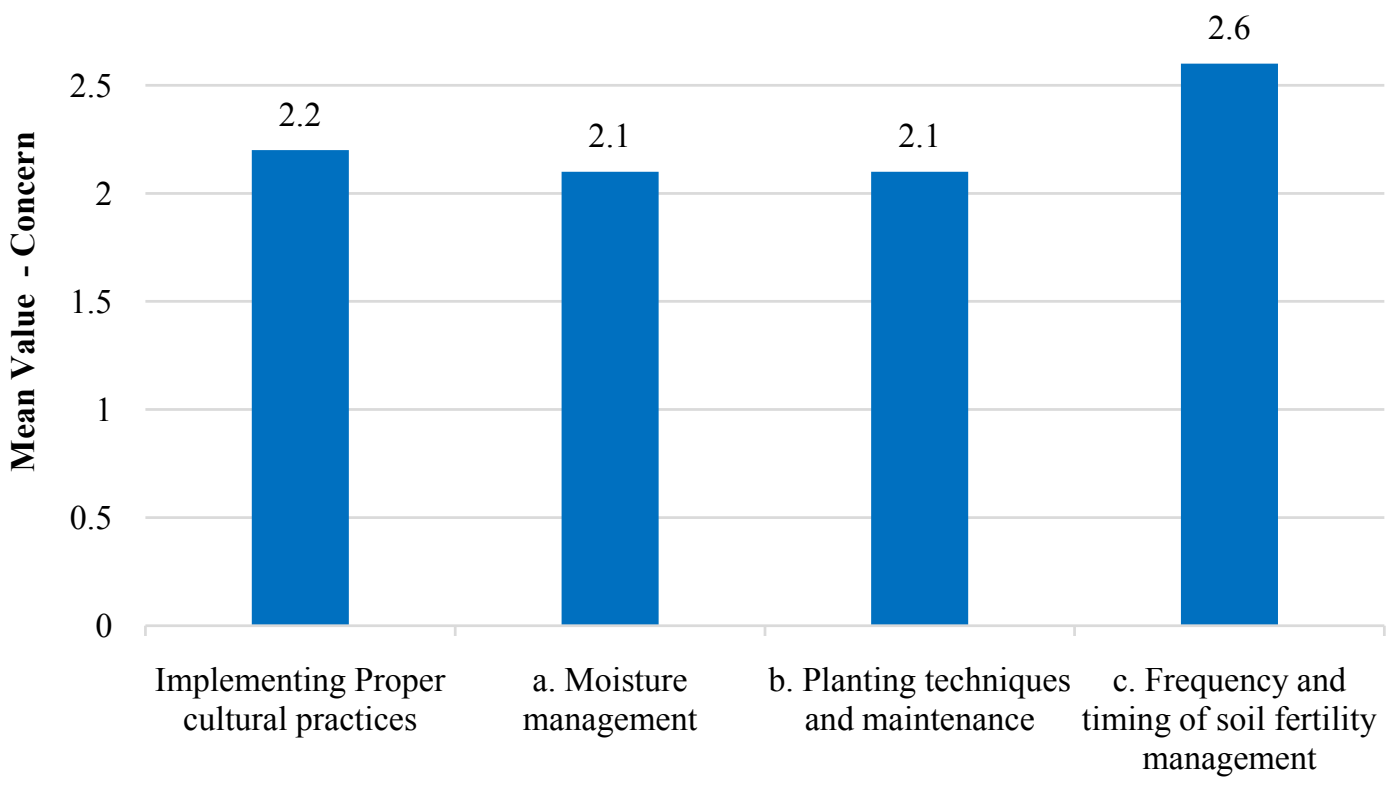

\section{Practices}

Figure 4. Implement proper cultural practices. 
main constraint to increase in productivity. They apply mainly composted pruned branches of tress and domestic wastes mainly for plants that shows urgent fertilizer requirement. Resource acquisition at differential rates by the dominant component is a major cause of production decrease in competing mixtures (Kumar, 2006). Intentionally growing Gliricidia trees (Gliricidia maculata-syn G. sepium) along the fences and different leguminous crops including Kathuru Murunga (Sesbania grandiflora), Winged bean (Psophocarpus tetragonolobus) etc., together with other crops and tress are common concern the fertility in the homegardens of the study area. They are well aware that high levels of on-site nutrient conservation in agroforestry homegardens generally create stable and partially self-generating ecosystem through mixture effects by improving the soil fertility. Indigenous knowledge systems of agroforestry in homegarden show that the households are knowledgeable about natural regeneration of productivity of land greater under native legume species than under non-legumes (Pinho et al., 2012).

The households little concern about the planting techniques and maintenance (2.1); and moisture management (2.1) during the performing of main cultural practices. Planting of different crops and tress in agroforestry system is a common practice in Sri Lanka to rehabilitate the degraded lands in homegardens experiencing soil erosion, soil fertility degradation as well as soil water conservation. Contribution of biodiversity conservation to soil fertility improvement and soil enrichment are considered by households as ecosystem services and environmental benefits through their long term experience. Agroforestry is an important option to rehabilitate soil fertility degraded lands in homegardens due to long term soil erosion (Mattsson et al., 2013). The land use system of homegarden agroforestry in tropical countries evolved over centuries in responding to changing rural livelihood conditions and ecological adaptive system (Kumar \& Tiwari, 2017).

\subsection{Management of Trees/Plant Health Care}

The overall households are moderately concern about scientific basis of the management of tree and plant health care (2.8) (Figure 5). The less input intensive agroforestry homegardens with woody perennial based mixtures are less productive and difficult to manage. However, with the time permits, most of the households are involving in different management practices and healthcare activities in their homegardens. The households determine the composition and density of the constituent species in agroforestry systems in homegardens in order to manage the biodiversity and healthy environment (Paembonan et al., 2018). They pay moderate concern on scientific basis about the prevention of the diseases (2.9); management of pests (2.8); and control of weeds (2.6). Intercropping with nitrogen fixing trees and crops, mulching to preserve soil moisture and control weeds as well as maintain compost pit for household wastes are common practices in homegardens. The households are able to manage the incidence 
3.5

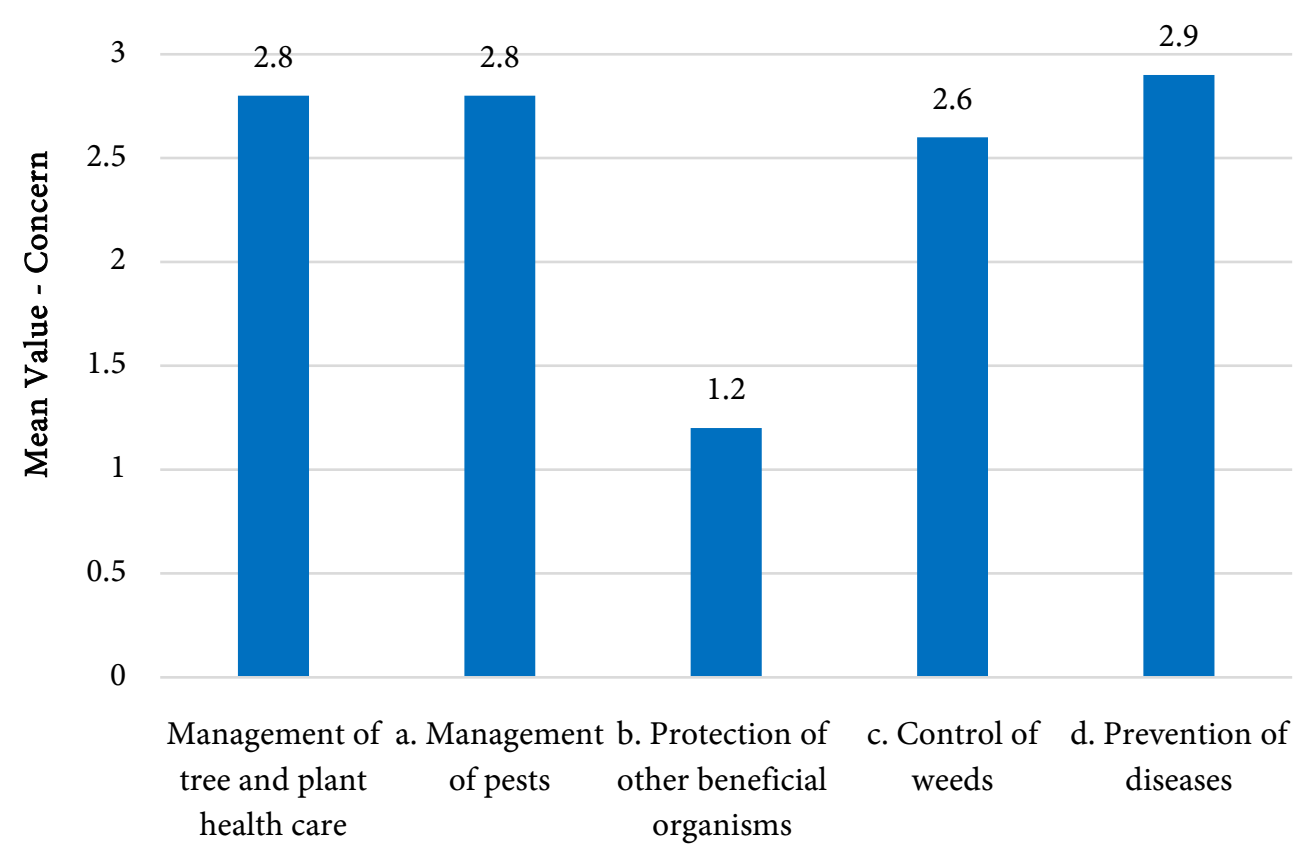

\section{Practices}

Figure 5. Management of trees/plant health care.

of pests and diseases even though they utilize lands of the homegardens for unplanned agroforestry practices. They remove damaged crops and vegetative parts of trees as well as change spatial arrangements of the agroforestry systems in homegardens to reduce spread of pest and disease. Agroforestry practices, despite the limited incidents, are effective in pest, disease and weed management (Pumariño et al., 2015). The studies have been rarely conducted even on the role of agroforestry systems in moderating the pest and disease incidence and allopathic influences which are very useful knowledge to be used in practice (Rao et al., 2007). Lack of such scientific knowledge of ecosystem resilience of agroforestry in homegarden may lead to destruction of plant diversity in practice (Linger, 2014).

Protection of other beneficial organisms is received no concern on scientific basis (1.2) by the households. The households are little knowledgeable about the role of agroforestry in homegardens for optimizing nutrient cycles and impacts on improving chemical and physical properties of soil. With the association of other organisms, diversity of plants in the homegarden to some extent contribute to the formation and maintenance of soil structure, retention of moisture and nutrient levels and promotes the recycling of nutrients (Verchot et al., 2007). Adding organic matter to the soil system and root exudates in the rhizosphere, and vast range of organisms in agroforestry involve in soil biological activity and interactions effects for soil nutrients and fertility (Bertin et al., 2003). 


\section{Relationship between Scientific Basis of Households Practices, and Size of Homegardens, Educational Level and Categories of Occupation}

\subsection{Size of Homegardens and Scientific Basis of Practices}

The "Pearson correlation coefficient, $r$ " indicates that there is no significant correlation between the size of homegardens and scientific basis of agroforestry practices of households ( $\mathrm{r}=0.055$, and $p=0.656)$ (Table 5). Size of the land of the homegarden is not an important concern for the scientific basis of practices of households for agroforestry. All the households have main intension to maintain beautiful homegardens through experiences without considering the size of the lands. The investment in the homegarden is not seen as a necessity and the return to labour is relatively low. According to Mattsson et al. (2017) a required closeness and intensity built into the land-use system of homegardens to be highly productive while it tends to get weaker with growing size.

The "Pearson correlation coefficient, $r$ " indicates that there is no significant correlation between the educational level of households and scientific basis of agroforestry practices $(\mathrm{r}=0.123$, and $p=0.316)$ of the households in the study area. Even though the human capital is improved with better education, the households concern scientific basis of agroforestry practices differently based on their level of education. It is argued that the level of education of households have positive and significant relationship in adopting agroforestry innovations as early adopters (Nkamleu \& Manyong, 2005). The education level of the household is irrelevant as they share the knowledge and experiences with their neighbours on agroforestry practices in homegardens. All the households interviewed have not been motivated positively according to the level of their education to use the scientific basis of agroforestry in homegardens practices. They often use their knowledge and experiences as well as exchange of information with their neighbours. The households develop knowledge through planting materials exchange systems among kin and neighbours without significant influence of formal education (Whitney et al., 2018).

\subsection{Scientific Basis of Practices and Households' Occupation}

"Kruskal-Wallis Test" indicates that there is no significant difference in scientific

Table 5. Correlations between size of homegardens, educational level of household and scientific basis of practices.

\begin{tabular}{lcccc}
\hline & Mean Value & $\begin{array}{c}{ }^{*} \text { Pearson } \\
\text { Correlation }-\mathrm{r}\end{array}$ & Sig. (2-tailed) & $\mathrm{N}$ \\
\hline Size of Homegardens & 0.37 & & & \\
Scientific basis of practices & 2.20 & 0.055 & 0.656 & 68 \\
Educational Level of household & 9.0 & & & \\
Scientific basis of practices & 2.20 & 0.123 & 0.316 & 68 \\
\hline
\end{tabular}

*Pearson correlation coefficient. 
basis of practices $\left(\chi^{2}=3.668, p=0.453\right)$ of the households on agroforestry homegardens across the category of their occupations (Table 6). The distribution of scientific basis of practices of the households on agroforestry homegardens have no significant difference across the category of their occupations as farmers, government jobs, private sector jobs, family business, and no proper occupation. They feel like common households despite their occupation while involving in homegarden activities often together with their family members. Households are dedicated and interested in performing various tasks in their homegardens utilizing available spare time while concentrating on other activities that required attention (Ortíz-Sánchez et al., 2015). The level of involvement of the households in agroforestry homegardens in the study area make no difference across the category of their occupations. For the adoption and diffusion process of scientific agroforestry proceeds among farming communities, occupation of the households is not a significant factor in home gardening. Many studies have proved that the socioeconomic features of the households can influence on tree selection, management and species diversity of homegardens. The structure and management of a homegarden varies from place to place and generally has a functional relationship with its occupants related to economic, biophysical and social aspects (Wekumbura et al., 2017).

\section{Improvement of Scientific Basis of Household Practices in Agroforestry Homegardens}

The analysis of the conditions required for improvement of the scientific basis of household practices in agroforestry homegardens in the study area were considered as: availability of scientific information; access to scientific knowledge; interest to acquire scientific knowledge; opportunity to improve scientific skills; sufficient time to improve scientific knowledge and skills; resources to use scientific knowledge in practice; and other requirements (Table 7 and Figure 6). Closing the gap between scientific basis of available knowledge and household practices is important for efficient dissemination of potential innovations (Scott et al., 2008). Knowledge, persuasion, decision, implementation, and confirmation is the five-step time-ordered sequence of an innovation-decision process required to reach an adoption of innovation by the beneficiaries (Rogers, 2003).

Table 6. Distribution of scientific basis of practices of households across the category of occupation.

\begin{tabular}{lcccc}
\hline & $\mathrm{N}$ & Chi-square $\left(\chi^{2}\right)$ & $\begin{array}{c}\text { Degree } \\
\text { of freedom }\end{array}$ & $\begin{array}{c}\text { Asymp. Sig. } \\
\text { (2-sided test) }\end{array}$ \\
\hline $\begin{array}{l}\text { Distribution of scientific } \\
\text { basis of practices across the } \\
\text { category of occupation }\end{array}$ & 68 & 3.668 & 4 & 0.453 \\
\hline
\end{tabular}

${ }^{\mathrm{a}}$ Kruskal-Wallis Test $\mathrm{H}$; ${ }^{\mathrm{b}}$ Grouping Variable: Occupation. 
Table 7. Improve scientific basis of agroforestry practices.

\begin{tabular}{lccccc}
\hline \multicolumn{1}{c}{ Households Concerns } & Mean & Median & St. Dev. & ${ }^{*}$ r & Sig. \\
\hline Availability of scientific information & 2.38 & 2.0 & 0.55 & 0.282 & $0.020^{\star *}$ \\
Access to scientific knowledge & 3.96 & 4.0 & 1.31 & 0.244 & $0.045^{\star *}$ \\
$\begin{array}{l}\text { Interest to acquire scientific knowledge } \\
\text { Opportunity to improve scientific skills }\end{array}$ & 2.47 & 2.0 & 0.72 & 0.115 & 0.349 \\
$\begin{array}{l}\text { Sufficient time to improve scientific } \\
\text { knowledge }\end{array}$ & 1.94 & 2.0 & 1.06 & 0.164 & 0.183 \\
$\begin{array}{l}\text { Resources to use scientific knowledge in } \\
\text { practice }\end{array}$ & 4.04 & 5.0 & 1.27 & 0.362 & $0.002^{* *}$ \\
\begin{tabular}{l} 
Other requirement \\
\hline
\end{tabular} & 1.69 & 2.0 & 0.47 & 0.022 & 0.861 \\
\hline
\end{tabular}

Likert Scale: Not concern-1; little concern-2; Moderate concern-3; highly concern-4; and fully concern $-5 ;{ }^{\star} \mathrm{r}-$ Pearson Correlation Coefficient; ${ }^{\star \star}$ Correlation is significant at the 0.05 level (2-tailed).

7. Other requirements

6. Resources to use scientific knowledge

5. Sufficient time to improve scientific knowledge

4. Opportunity to improve scientific skills

3. Interest to acquire scientific knowledge

2. Access to scientific knowledge

1. Availability of scientific information

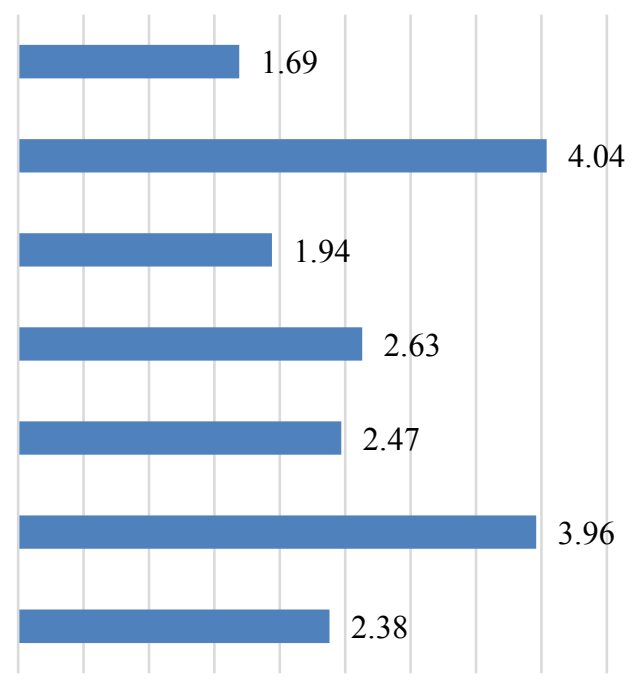

$\begin{array}{llllllllll}0 & 0.5 & 1 & 1.5 & 2 & 2.5 & 3 & 3.5 & 4 & 4.5\end{array}$

Mean Value

Figure 6. Improvement of scientific basis.

\subsection{Resources to Use Scientific Knowledge and Opportunity to Improve Scientific Skills}

The values of Pearson Correlation Coefficient " $r$ " indicate that the concerning resources to use scientific knowledge in practice $(\mathrm{r}=0.362, p=0.002)$, and opportunity to improve scientific skills $(\mathrm{r}=0.343, p=0.004)$ have moderately significant correlation for the improvement of practices based on scientific basis in agroforestry homegardens by the households. Resource endowments of the households determine the scientific basis of agroforestry practices in homegardens. Households are not empowered through provision of agricultural inputs such as agricultural credit, subsidy fertilizers etc., as given to agriculture sector 
to improve the production quantities of homegardens in the study area. Sufficient amount of seeds and seedlings in preferred species are not been distributed to meet the needs of households to improve their agroforestry homegardens. Lack of planting materials in preferred species is an often limitation for the adoption of innovation in agroforestry practices (Kwesiga et al., 2003). Establishment of input supply networks and provision of required material would allow the households to maintain agroforestry in homegardens that are resilient to their changing economic, social and environmental conditions (Whitney et al., 2018).

There is no proper extension and training program, and other facilities available for the households to improve their scientific skills for the promotion of agroforestry homegardens in the study area. Extension and training are far more significant and obviously important factors of adoption of agroforestry technology (Pattanayak et al., 2003). Extension contacts are of paramount importance in changing the mind set and developing favorable attitude of households towards scientific basis of agroforestry practices (Matata et al., 2010). Provision of extension services, knowledge skills, training and incentives on homegardens management, could be used to improve agroforestry systems and enhance the homegardens productivity by the households. Education and extension programs, financial incentives, and creation of markets for agroforestry products make incentives to take up scientific basis of agroforestry practices (Brown et al., 2018). Sri Lanka has no government policy to support implementation of strategies and enhance adoption of scientific basis of homegardens. Even the existing agroforestry policies do not pay sufficient incentive for adaptive research in order to provide for adequate promotion of scientific basis for agroforestry practices in homegardens. Extension agencies do not pay sufficient attention for agroforestry as a land use option due to lack of policy support (Kumar, 2006). Policy instruments which promote many traditional agroforestry systems in many Asian countries are either lacking or inadequate (Kumar \& Nair, 2004). The level of delivery of extension services as well as incentives which tied management of the trees at different stages are improved by research and extension projects from development partners promoting agroforestry practices (Phiri et al., 2004).

\subsection{Availability of Scientific Information and Access to Scientific Knowledge}

Availability of scientific information $(\mathrm{r}=0.282, p=0.020)$ and access to scientific knowledge ( $\mathrm{r}=0.244, p=0.045)$ have significant but low correlation as applying knowledge on scientific basis of agroforestry in homegardens by the households. Development projects concentrate on homegardens in Sri Lanka make very little scientific effort due to lack research findings and updated knowledge to increase the productivity of the agroforestry systems. The low levels of awareness of scientific basis of certain agroforestry practices attribute to the low levels of adoptions by the households in the study area. They make little effort to 
search for scientific information and looking for potential sources of information to promote agroforestry in homegardens. They often change the agroforestry composition and management practice using their long-term experiences or advises from the neighbours to face particularly the environmental and ecological hazards. The households require scientific information to maintain ecosystem resilience of agroforestry homegardens and to meet their requirements during stress of climatic hazard like drought and flood (Linger, 2014). Lack of extension service to disseminate technical know-how specially designed for agroforestry in homegardens create poor access to scientific knowledge for households and constraint them to attain to scientific practices in their homegardens. Scientific information induce the adoption and diffusion of technological innovation across a population (Sarkar, 2002). Although the well-established extension services is available for the promotion of agriculture in Sri Lanka, they are not competent in disseminating scientific knowledge and information effectively in promoting agroforestry in homegardens in the study area. An adequate extension service and improved working environment of extension staff to enhance the technology transfer to the households effectively is a mile stone for the homegardens improvement (Maroyi, 2009).

However, according to the households, the information about many traditional agroforestry land-use practices in homegardens are either not available, or the available information is rarely complete. They often use a blend of traditional knowledge and some scientific knowledge developed through long-term trails and errors using experiences. Indigenous knowledge on agroforestry homegardens need to be transformed by scientific knowledge through both on-station and on-farm research to scaling-up to sustainable production systems (Mehari \& Abera, 2019). Research endeavours in agroforestry developed along strict disciplinary lines often neglect the traditional land use practices in agroforestry homegardens (Nair \& Kumar, 2006). There is no properly organized institutional initiative in Sri Lanka to promote homegardens despite some researcher-motivated individual efforts. Adopting a practice of agroforestry systems are based on researcher-led and participatory on-farm research methods (Franzel \& Scherr, 2002).

\subsection{Interest to Acquire Scientific Knowledge, Sufficient Time to Improve Scientific Knowledge and Other Reasons}

Interest to acquire scientific knowledge $(\mathrm{r}=0.115, p=0.349)$, and sufficient time to improve scientific knowledge $(\mathrm{r}=0.164, p=0.183)$, and other reasons $(\mathrm{r}=$ $0.022, p=0.861$ ) have no significant correlation with practices agroforestry in homegardens on scientific basis by the households. A study conducted in Sri Lanka has revealed that the households are not interested to develop their homegardens even under the strong encouragement and persuasion by the local government program (Bandara, 2015). Unless there is an organized program, the households in the study area have no special interest to acquire scientific 
knowledge making special effort and intentionally develop the scientific basis of agroforestry systems in their homegardens. However, planned behaviour reflects the level of motivation a person is willing to exert to perform the behaviour (Ajzen, 1991). Since the households do home gardening on personal interest during their leisure time, they are not willing to be organized to promote scientific basis of the agroforestry systems. Strategic interactions among households rather than differences in household characteristics determine why individual households take time to switch between old and new technologies (Sarkar, 2002).

An opportunity to develop a household society has not yet been emerged in the study area for sharing and expansion of the scientific basis of their knowledge and skills for the management of flowers, shrubs, herbs, vegetables in their homegardens. Social relations among gardeners influence exchange of knowledge and plant material among the members of the society and the species diversity and plant richness in their homegardens (Díaz-Reviriego et al., 2016). The households do not find any relationship between the time availability and the acquiring of scientific basis for their agroforestry practices in the homegarden. They often spend their leisure time in the homegardens as a meeting place of the family members, enjoying aesthetic values and relaxing in fresh environment, sharing pleasure with family for harvested fresh crops, fruits and vegetables from the homegardens. However, they do not disagree that they would find time to read any printed materials or watch media program disseminating scientific knowledge on home gardening. The high publicity given to the Divinaguma Homegarden Programme in Sri Lanka has created huge initial impression and stimulated large number of households to promote home gardening (Jayampathi et al., 2015). Awareness creation is a promising strategy to encourage the households to scale-up homegardens with appropriate components (Mehari \& Abera, 2019).

\section{Conclusion and Policy Implications}

\subsection{Conclusion}

The relatively small homegardens in the study area are managed by the households headed by the majority of with upper secondary education and involving in non-farming occupations. The extents covering agroforestry components are dominated by ornamental plants, fruit trees and vegetables respectively. The households moderately concern scientific basis on requirement of plants, and drought and disease resistant varieties/cultivars while little concern on growing right plant in right place, and selecting appropriate trees and plants. They moderately concern scientific basis on prevention of diseases, management of pests and control of weeds but not concern the protection of beneficial organisms. They moderately concern the scientific basis in management of soil fertility and conservation as well as the direction of wind while little concern on access to the sun light, convenience for management practices, and the supply of water. Arranging water drainage system and preparing soil conservation structures is 
moderately concern while altering light conditions and amending soil acidity are little concerned on scientific basis by the households. Implementing proper cultural practices particularly the moisture management and planting techniques and maintenance are little concerned but the frequency and timing of soil fertility management is moderately concerned on scientific basis by the households. The size of homegardens, educational level of households, and across the category of their occupations has no correlation with scientific basis of their agroforestry practices. Improvement of scientific information, dissemination of scientific knowledge and development of scientific skills are important strategies to promote scientific basis of household practices for agroforestry homegardens.

\subsection{Policy Implications}

Carefully planned interventions including comprehensive participatory research, policy adjustments and effective extension programs for learning and experimenting couple with resources to use scientific knowledge in practice, opportunity to improve scientific skills, availability of scientific information, and access to scientific knowledge would enhance scientific basis of household practices for agroforestry in homegardens.

\section{Acknowledgements}

The author thanks the responded households for granting access and providing information about their agroforestry homegardens where this study was undertaken. Moreover, the officers of the study area who gave me directions, and critical comments and suggestions have greatly helped the authors to improve the quality of the study.

\section{Conflicts of Interest}

The author declares no conflicts of interest regarding the publication of this paper.

\section{References}

Ajzen, I. (1991). The Theory of Planned Behaviour. Organizational Behaviour and Human Decision Processes, 50, 179-211. https://doi.org/10.1016/0749-5978(91)90020-T

Ali, M. M., Rahman, M. M., Islam, S., Islam, M. A., Alam, M. R., Bari, M. S., \& Nahar, M. N. (2018). Varietal Performance of Turmeric under Mango Based Agroforestry System. American Journal of Plant Sciences, 9, 995-1003. https://doi.org/10.4236/ajps.2018.95076

Amenu, B. T. (2017). Home Garden Agro-Forestry Practices and Its Contribution to Rural Livelihood in Dawro Zone Essera District. Journal of Environment and Earth Science, 7, 88-96. https://www.iiste.org/Journals/index.php/JEES/article/view/36982

Baig, M. B., Ahmad, S., Khan, N., \& Khurshid, M. (2008). Germplasm Conservation of Multipurpose Trees and Their Role in Agroforestry for Sustainable Agricultural Production in Pakistan. International Journal of Agriculture and Biology, 10, 340-348. https://agris.fao.org/agris-search/search.do?recordID=PK2009000320

Bandara, T. W. M. T. W. (2015). Modern Trends and Distribution Patterns of Kitchen 
Gardens in Sri Lanka (A Case Study in Biyagama Area). Social Sciences and Humanities Review, 2, 27-58. https://www.researchgate.net/publication/308720658

Bardhan, S., Jose, S., Biswas, S., Kabir, K., \& Rogers, W. (2012). Homegarden Agroforestry Systems: An Intermediary for Biodiversity Conservation in Bangladesh. Agroforestry Systems, 85, 29-34.

Bertin, C., Yang, X., \& Weston, L. A. (2003). The Role of Root Exudates and Allelochemicals in the Rhizosphere. Plant and Soil, 256, 67-83. https://doi.org/10.1023/A:1026290508166

Boshoff, N. (2014). Types of Knowledge in Science-Based Practices. Journal of Science Communication, 13, Article No. A06. https://doi.org/10.22323/2.13030206

Brown, S. E., Miller, D. C., Ordonez, P. J., \& Baylis, K. (2018). Evidence for the Impacts of Agroforestry on Agricultural Productivity, Ecosystem Services, and Human Well-Being in High-Income Countries: A Systematic Map Protocol. Environmental Evidence, 7, Article No. 24. https://doi.org/10.1186/s13750-018-0136-0

Chokkalingam, U., \& Vanniarachchy, S. A. (2011). Sri Lanka's REDD Potential: Myth or Reality? Forest Carbon Asia Country Profile Report No. 1: Sri Lanka. Forest Carbon Asia.

https://www.researchgate.net/publication/263853129_Sri_Lanka's_REDD_Potential_M yth_or_Reality

Climate Change Secretariat, Ministry of Mahaweli Development and Environment (2016). National Adaptation Plan for Climate Change Impacts in Sri Lanka: 2016-2025 (pp. 35-36). Ministry of Mahaweli Development and Environment.

https://www4.unfccc.int/sites/NAPC/Documents\%20NAP/National\%20Reports/Natio nal\%20Adaptation\%20Plan\%20of\%20Sri\%20Lanka.pdf

DeHaan, R., \& Odame, H. H., Thevathasan, N., \& Nissanka S. P. (2020). Local Knowledge and Perspectives of Change in Homegardens: A Photovoice Study in Kandy District, Sri Lanka. Sustainability, 12, Article No. 6866. https://doi.org/10.3390/su12176866

Díaz-Reviriego, I., González-Segura, L., Fernández-Llamazares, A., Howard, P. L., Molina, J., \& Reyes-García, V. (2016). Social Organization Influences the Exchange and Species Richness of Medicinal Plants in Amazonian Homegardens. Ecology and Society, 21, Article No. 1. https://doi.org/10.5751/ES-07944-210101

Dundar, H., Millot, B., Riboud, M., Shojo, M., Aturupane, H., Goyal, S., \& Raju, D. (2017). Sri Lanka Education Sector Assessment: Achievements, Challenges, and Policy Options. Directions in Development-Human Development. World Bank. https://openknowledge.worldbank.org/bitstream/handle/10986/27042/9781464810527. pdf? sequence $=2$ \&isAllowed $=\mathrm{y}$ https://doi.org/10.1596/978-1-4648-1052-7

FAO (Food and Agriculture Organization of the United Nations) (2017). FAO and the Ministry of Education Support School Garden Initiative for Better Nutrition in Sri Lanka. http://www.fao.org/srilanka/news/detail-events/en/c/903187/

FAO (Food and Agriculture Organization of the United Nations) (2009). Sri Lanka Forestry Outlook Study. Working Paper No. APFSOS II/WP/2009/29, FAO Regional Office for Asia and the Pacific. http://www.fao.org/3/am624e/am624e00.pdf

Franzel, S., \& Scherr, S. J. (Eds.) (2002). Trees on the Farm: Assessing the Adoption Potential of Agroforestry Practices in Africa (p. 82). Centre for Agriculture and Biosciences International. https://doi.org/10.1079/9780851995618.0000 https://pdfs.semanticscholar.org/c0ab/c028bc1d351eeac80b8341dfb6de71060564.pdf? $\mathrm{ga}=2.166016189 .227206261 .1615101124-871681002.1557299232$

Galhena, D. H., Freed, R., \& Maredia, K. M. (2013). Home Gardens: A Promising Ap- 
proach to Enhance Household Food Security and Wellbeing. Agriculture \& Food Security, 2, Article No. 8. https://doi.org/10.1186/2048-7010-2-8

Gifawesen, S. T., Tola, F. K., \& Duguma, M. S. (2020). Review on Role of Home Garden Agroforestry Practices to Improve Livelihood of Small Scale Farmers and Climate Change Adaptation and Mitigation. Journal of Plant Sciences, 8, 134-145.

http://www.sciencepublishinggroup.com/j/jps

Huai, H., \& Hamilton, A. (2009). Characteristics and Functions of Traditional Homegardens: A Review. Frontiers in Biology, 4, 151-157. https://doi.org/10.1007/s11515-008-0103-1

Jayampathi, C., Senanayake, M. S., Epakanda, N. S. B., \& Samarakoon, S. M. A. (2015). Evaluation of Divinaguma Agriculture Component-Homegardens. Hector Kobbekaduwa Agrarian Research and Training Institute. http://library.statistics.gov.lk/cgi-bin/koha/opac-detail.pl?biblionumber $=8733$

Jeyavanan, K., Sivachandiran, S., \& Pushpakumara, D. K. N. G. (2017). Ecosystem Services of Homegarden Agroforestry in Jaffna Peninsula. Journal of Dry Zone Agriculture, 3, 56-68.

Jose, S. (2009). Agroforestry for Ecosystem Services and Environmental Benefits: An Overview. Agroforestry Systems, 76, 1-10. https://doi.org/10.1007/s10457-009-9229-7

Kabir, M. E., \& Webb, E. L. (2009). Household and Homegarden Characteristics in South Western Bangladesh. Agroforestry Systems, 75, Article No. 129. https://doi.org/10.1007/s10457-008-9142-5

Kumar, B. M. (2006). Agroforestry: The New Old Paradigm for Asian Food Security. Journal of Tropical Agriculture, 44, 1-14. https://www.researchgate.net/publication/257374378_Agroforestry_the_new_old_para digm_for_Asian_food_security

Kumar, B. M., \& Nair, P. K. R. (2004). The Enigma of Tropical Homegardens. Agroforestry Systems, 61, 135-152. https://doi.org/10.1023/B:AGFO.0000028995.13227.ca

Kumar, V., \& Tiwari, A. (2017). Importance of Tropical Homegardens Agroforestry System. International Journal of Current Microbiology and Applied Sciences, 6, 1002-1019. https://doi.org/10.20546/ijcmas.2017.609.122

Kwesiga, F., Akinnifesi, F. K., Mafongoya, P. L., McDermott, M. H., \& Agumya, A. (2003). Agroforestry Research and Development in Southern Africa during the 1990s: Review and Challenges Ahead. Agroforestry Systems, 59, 173-186. https://doi.org/10.1023/B:AGFO.0000005222.68054.38

Linger, E. (2014). Agro-Ecosystem and Socio-Economic Role of Homegarden Agroforestry in Jabithenan District, North-Western Ethiopia: Implication for Climate Change Adaptation. SpringerPlus, 3, Article No. 154. https://doi.org/10.1186/2193-1801-3-154

Liu, W., Yao, S., Wang, J., \& Liu, M. (2019). Trends and Features of Agroforestry Research Based on Bibliometric Analysis. Sustainability, 11, Article No. 3473. https://doi.org/10.3390/su11123473

Maroyi, A. (2009). Traditional Homegardens and Rural Livelihoods in Nhema, Zimbabwe: A Sustainable Agroforestry System. International Journal of Sustainable Development and World Ecology, 16, 1-8. https://doi.org/10.1080/13504500902745895

Matata, P., Ajayi, O. C., Oduol, P. A., \& Agumya, A. (2010). Socio-Economic Factors Influencing Adoption of Improved Fallow Practices among Smallholder Farmers in Western Tanzania. African Journal of Agricultural Research, 5, 818-823. http://www.academicjournals.org/AJAR

Mattsson, E., Ostwald M., \& Nissanka S. P. (2013). Homegardens as a Multi-functional 
Land-Use Strategy in Sri Lanka with Focus on Carbon Sequestration. AMBIO, 42, 892-902. https://doi.org/10.1007/s13280-013-0390-x

Mattsson, E., Ostwald, M., \& Nissanka, S. P. (2017). What Is Good about Sri Lankan Homegardens with Regards to Food Security? A Synthesis of the Current Scientific Knowledge of a Multifunctional Land-Use System. Agroforestry Systems, 92, 1469-1484. https://doi.org/10.1007/s10457-017-0093-6

Mbow, C., van Noordwijk, M., Prabhu, R., \& Simons, T. (2014). Knowledge Gaps and Research Needs Concerning Agroforestry's Contribution to Sustainable Development Goals in Africa. Current Opinion in Environmental Sustainability, 6, 162-170. https://doi.org/10.1016/j.cosust.2013.11.030

Mehari, A. B., \& Abera, M. W. (2019). Opportunities and Challenges of Adopting Home Garden Agroforestry Practices in Ethiopia: A Review. Cogent Food \& Agriculture, 5, Article ID: 1618522. https://doi.org/10.1080/23311932.2019.1618522

Nair, P. K. R. (1993). An Introduction to Agroforestry. Springer. https://www.springer.com/gp/book/9780792321347

Nair, P. K. R. (2001). Do Tropical Homegardens Elude Science, or Is It the Other Way Around? Agroforestry Systems, 53, 239-245. https://doi.org/10.1023/A:1013388806993

Nair, P. K. R. (2007). Perspective: The Coming of Age of Agroforestry. Journal of the Science of Food and Agriculture, 87, 1613-1619. https://doi.org/10.1002/jsfa.2897

Nair, P. K. R., \& Kumar, B. M. (2006). Introduction. In B. M. Kumar, \& P. K. R. Nair (Eds.), Tropical Homegardens: A Time-Tested Example of Sustainable Agroforestry (Vol. 3, 1-10). Springer Science. https://doi.org/10.1007/978-1-4020-4948-4_1 https://link.springer.com/book/10.1007/978-1-4020-4948-4\#toc

National Council for Sustainable Development (NCSD) (2009). Sri Lanka: National Action Plan for Haritha Lanka Programme. National Council for Sustainable Development, Presidential Secretariat. https://policy.asiapacificenergy.org/node/2744

Nkamleu, G. B., \& Manyong, V. M. (2005). Factors Affecting the Adoption of Agroforestry Practices by Farmers in Cameroon. Small-Scale Forest Economics, Management and Policy, 4, 135-148. https://doi.org/10.1007/s11842-005-0009-6

Ong, C. K., \& Swallow, B. M. (2004). Water Productivity in Forestry and Agroforestry. In M. van Noordwijk, G. Cadisch, \& C. K. Ong (Eds.), Belowground Interactions in Multiple Agroecosystems (pp. 23-24). CAB International. https://www.cabi.org/bookshop/book/9780851996738/

Ortíz-Sánchez, A., Monroy-Ortiz, C., Romero-Manzanarez, A., Luna-Cavazos, M., \& Castillo-España, P. (2015). Multipurpose Function of Home Gardens in the Family Subsistence. Botanical Sciences, 93, 791-806. https://doi.org/10.17129/botsci.224

Paembonan, S. A., Millang, S., Dassir, M., \& Ridwan, M. (2018). Species Variation in Home Garden Agroforestry System in South Sulawesi, Indonesia and Its Contribution to Farmers' Income. IOP Conference Series: Earth and Environmental Science, 157, Article ID: 012004. https://doi.org/10.1088/1755-1315/157/1/012004 https://iopscience.iop.org/article/10.1088/1755-1315/157/1/012004

Park, J. H., Woo, S. Y., Kwak, M. J., Lee, J. K., Leti, S., \& Soni, T. (2019). Assessment of the Diverse Roles of Home Gardens and Their Sustainable Management for Livelihood Improvement in West Java, Indonesia. Forests, 10, Article No. 970. https://doi.org/10.3390/f10110970

Pattanayak, S. K., Mercer, D. E., Sills, E., \& Yang, J. (2003). Taking Stock of Agroforestry Adoption Studies. Agroforestry Systems, 57, 173-186.

https://doi.org/10.1023/A:1024809108210 
Phiri, D., Franzel, S., Mafongoya, P., Jere, I., Katanga, R., \& Phiri, S. (2004). Who Is Using the New Technology? The Association of Wealth Status and Gender with the Planting of Improved Tree Fallows in Eastern Province, Zambia. Journal of Agricultural Systems, 79, 131-144. https://doi.org/10.1016/S0308-521X(03)00055-6

Pinho, R. C., Miller, R. P., \& Alfaia, S. S. (2012). Agroforestry and the Improvement of Soil Fertility: A View from Amazonia. Applied and Environmental Soil Science, 2012, Article ID: 616383.

Pumariño, P., Sileshi, G. W., Gripenberg, S., Kaartinen, R., Barrios, E., Muchane, M. N., Midega C., \& Jonsson, M. (2015). Effects of Agroforestry on Pest, Disease and Weed Control: A Meta-Analysis. Basic and Applied Ecology, 16, 573-582. https://doi.org/10.1016/j.baae.2015.08.006

Pushpakumara, D. K. N. G., Marambe, B., Silva, G. L. L. P., Weerahewa, J., \& Punyawardena, B. V. R. (2012). A Review of Research on Homegardens in Sri Lanka. The Status, Importance and Future Perspective. Tropical Agriculturist, 160, 55-125.

https://www.researchgate.net/publication/236117466

Rao, K. P. C., Verchot, L. V., \& Laarman, J. (2007). Adaptation to Climate Change through Sustainable Management and Development of Agroforestry Systems. SAT eJournal, 4, 1-30. http://oar.icrisat.org/2561/1/Adaptation_to_Climate_Change.pdf

Rogers, E. M. (2003). Diffusion of Innovations (5th ed.). Simon and Schuster. https://books.google.lk/books/about/Diffusion_of_Innovations_5th_Edition.html?id=9 U1K5LjUOwEC\&redir_esc=y

Sarkar, J. (2002). Technological Diffusion: Alternative Theories and Historical Evidence. Journal of Economic Surveys, 12, 131-176. https://doi.org/10.1111/1467-6419.00051

Scott, S. D., Plotnikoff, R. C., Karunamuni, N., Bize R., \& Rodgers, W. (2008). Factors Influencing the Adoption of an Innovation: An Examination of the Uptake of the Canadian Heart Health Kit (HHK). Implementation Science, 3, Article No. 41. https://doi.org/10.1186/1748-5908-3-41

Sinclair, F. L. (1999). A General Classification of Agroforestry Practice. Agroforestry Systems, 46, 161-180. https://doi.org/10.1023/A:1006278928088

Thamilini, J., Wekumbura, C., Mohotti, A. J., Kumara, A. P., Kudagammana, S. T., Silva, K. D. R. R., \& Frossard, E. (2019). Organized Homegardens Contribute to Micronutrient Intakes and Dietary Diversity of Rural Households in Sri Lanka. Frontiers in Sustainable Food Systems, 3, Article No. 94. https://doi.org/10.3389/fsufs.2019.00094

Thangata, P. H., \& Alavalapati, J. R. (2003). Agroforestry Adoption in Southern Malawi: The Case of Mixed Intercropping of Gliricidia sepium and Maize. Agricultural Systems, 78, 57-71. https://doi.org/10.1016/S0308-521X(03)00032-5

Thiago, A., Leonilde, D. S., Maria, M. D., Clodoaldo, A. A., Denise, C. L., \& Alan, P. A. (2016). Chemical Properties of Soils in Agroforestry Homegardens and Other Land Use Systems in Eastern Amazon, Brazil. African Journal of Agricultural Research, 11, 2616-2622. https://doi.org/10.5897/AJAR2016.11036

Verchot, L. V., Van Noordwijk, M., Kandji, S., Tomich, T., Ong, C., Albrecht, A., Mackensen, J., Bantilan, C., Anupama, K. V., \& Palm, C. (2007). Climate Change: Linking Adaptation and Mitigation through Agroforestry. Mitigation and Adaptation Strategies for Global Change, 12, 901-918. https://doi.org/10.1007/s11027-007-9105-6

Wekumbura, W. G. C., Mohotti, A. J., Frossard, E., Kudagammana, S. T., \& Silva, K. D. R. R. (2017). Prospects and Issues Related to Tea Cultivation in Mid Country: Homegarden Based Tea Smallholdings in a Selected Village in Sri Lanka. Tropical Agricultural Research, 28, 503-516. https://doi.org/10.4038/tar.v28i4.8250

Whitney, C. W., Luedeling, E., Nyamukuru A. T., Hensel, O., Gebauer, J., \& Kehlenbeck, 
K. (2018). Crop Diversity in Homegardens of Southwest Uganda and Its Importance for Rural Livelihoods. Agriculture and Human, 35, 399-424.

https://doi.org/10.1007/s10460-017-9835-3

Yapa, L. G. D. S. (2018). Contribution of Home Gardens to Household Food Security in Sri Lanka: A Comparative Study on Wet Zone and Intermediate Zone. Journal of Social Sciences and Humanities Review, 3, 124-132. https://doi.org/10.4038/jsshr.v3i3.11 